\title{
Technologies for the treatment of source-separated urine in the eThekwini Municipality
}

\author{
Kai M Udert ${ }^{*}$, Chris A Buckley², Michael Wächter1,3, Christa S McArdell', Tamar Kohn", Linda Strande', \\ Hanspeter Zöllig ${ }^{1}$, Alexandra Fumasoli ${ }^{1}$, Astrid Oberson ${ }^{5}$ and Bastian Etter ${ }^{1}$ \\ ${ }^{1}$ Eawag, Swiss Federal Institute of Aquatic Science and Technology, 8600 Dübendorf, Switzerland \\ ${ }^{2}$ Pollution Research Group, School of Chemical Engineering, University of KwaZulu-Natal, Durban 4041, South Africa \\ ${ }^{3}$ Enswico AG, 8132 Egg, Switzerland \\ ${ }^{4}$ Ecole Polytechnique Fédérale de Lausanne (EPFL), Environmental Chemistry Laboratory, School of Architecture, Civil and Environmental Engineering \\ (ENAC), 1015 Lausanne, Switzerland \\ ${ }^{5}$ Swiss Federal Institute of Technology (ETH) Zurich, Institute of Agricultural Sciences, 8315 Lindau, Switzerland
}

\begin{abstract}
In recent years, a large number of urine-diverting dehydration toilets (UDDTs) have been installed in eThekwini to ensure access to adequate sanitation. The initial purpose of these toilets was to facilitate faeces drying, while the urine was diverted into a soak pit. This practice can lead to environmental pollution, since urine contains high amounts of nutrients. Instead of polluting the environment, these nutrients should be recovered and used as fertiliser. In 2010 the international and transdisciplinary research project VUNA was initiated in order to explore technologies and management methods for better urine management in eThekwini. Three treatment technologies have been chosen for the VUNA project. The first is struvite precipitation, a technology which has already been tested in multiple projects on urine treatment. Struvite precipitation is a simple and fast process for phosphorus recovery. Other nutrients, such as nitrogen and potassium, remain in the effluent and pathogens are not completely inactivated. Therefore, struvite precipitation has to be combined with other treatment processes to prevent environmental pollution and hygiene risks. The second process is a combination of nitrification and distillation. This process combination is more complex than struvite precipitation, but it recovers all nutrients in one concentrated solution, ensures safe sanitisation and produces only distilled water and a small amount of sludge as by-products. The third process is electrolysis. This process could be used for very small on-site reactors, because conversion rates are high and the operation is simple, as long as appropriate electrodes and voltages are used. However, nitrogen is removed and not recovered and chlorinated by-products are formed, which can be hazardous for human health. While urine electrolysis requires further research in the laboratory, struvite precipitation and nitrification/distillation have already been operated at pilot scale.
\end{abstract}

Keywords: Sanitation, source separation, nutrient recovery, eutrophication, hygiene, human health

\section{BACKGROUND}

In 2001, the South African Government issued a White Paper on Basic Household Sanitation (DWAF, 2001) with the aim of clearing the sanitation backlog by 2014. In response, the eThekwini Municipality's Water and Sanitation Unit (EWS) started an integrated development planning (IDP) process to provide basic water and sanitation to peri-urban and rural areas in the metropolitan area of Durban (Gounden et al., 2006). In addition to providing $200 \ell$ of free potable water per household and day, EWS installed urine-diverting dry toilets (UDDTs) to achieve access to sanitation. Urine diversion was chosen for several reasons:

- Building waterborne sewage infrastructure was too costly and water supplies were limited

- Emptying of conventional ventilated improved pit latrines (VIPs) was costly and access for collection and transport trucks was often problematic

- After a sufficiently long dehydration time, faeces could be safely disposed of on-site

This paper was originally presented at the 2014 Water Institute of Southern Africa (WISA) Biennial Conference, Mbombela, 25-29 May 2014.

* To whom all correspondence should be addressed.

ฮ +41587655360; e-mail: kai.udert@eawag.ch
- No new pits would have to be periodically excavated

- The risk of environmental pollution would be limited

Initially, urine was not collected but infiltrated into the ground via a soak pit. The implementation of the new sanitation system was successful given that about 75000 households had received UDDTs by 2013. However, a survey conducted in December 2010 and January 2011 revealed that user satisfaction was low (Roma et al., 2013).

To increase the acceptance and sustainability of the UDDTbased sanitation approach, the research project VUNA was initiated by the Swiss Federal Institute of Aquatic Science and Technology (Eawag), EWS, the University of KwaZulu-Natal and the Swiss Federal Institute of Science and Technology in Zurich. The VUNA project is based on the vision that nutrient recovery from urine lowers the cost of sanitation, provides a valuable local fertiliser and reduces pollution of water resources. The project partners are guided by the belief that these advantages can lead to a higher acceptance of urine separation and sanitation in general.

In this paper, we will focus on the technical aspects of the VUNA project. After discussing challenges of urine treatment, we will present the processes which have been chosen for the VUNA project, and we will discuss some of the project results. 


\section{COMPOSITION OF STORED URINE}

Urine which has been collected in UDDTs is very different from fresh urine (Udert et al., 2006). In the collection tanks, urea and other organic substances are degraded by bacteria. The results are high ammonia concentrations, a high $\mathrm{pH}$ value and a strong, pungent smell caused by organic degradation products (Udert et al., 2003a; Troccaz et al., 2013). Due to the high pH value, nearly half of the nitrogen can volatilise as free ammonia (Siegrist et al., 2013). The high pH value also triggers the precipitation of about $30 \%$ of the phosphate as calcium phosphate and struvite (Udert et al., 2006). Tables 1 and 2 provide overviews of the composition of stored urine. Urine contains the majority of the nutrients in household wastewater, with the main nutrients being nitrogen, phosphorus, potassium and sulphur (Larsen and Gujer, 1996). Due to cross-contamination from faeces, urine can contain pathogens (Höglund et al., 1998), so that sanitisation measures have to be considered when treating urine. In recent years, pollution by trace organic contaminants, particularly pharmaceutical residues, has caught much attention among scientists, environmental protection agencies and the public. These trace organic compounds can have adverse effects on ecosystems and their organisms. Based on current studies, direct adverse health effects from pharmaceuticals occurring in drinking water are not expected (Bruce et al., 2010), however, possible chronic effects on humans may still be unknown. Our measurements have shown a high content of pharmaceutical residues in urine, especially of antibiotics, in the peri-urban areas of Durban (authors own unpublished data).

\begin{tabular}{|c|c|c|}
\hline \multicolumn{3}{|c|}{$\begin{array}{l}\text { TABLE } 1 \\
\text { Compounds in stored urine, their reuse potential and possible negative effects }\end{array}$} \\
\hline Compound & Beneficial reuses & Negative impacts \\
\hline Water & Recycling, for example for irrigation & $\begin{array}{l}\text { Water volume requires large storage tanks } \\
\text { Water weight makes transport expensive }\end{array}$ \\
\hline Nitrogen & $\begin{array}{l}\text { Fertiliser } \\
\text { Raw product for chemical industry }\end{array}$ & $\begin{array}{l}\text { Smell and toxicity of gaseous ammonia } \\
\text { Environmental pollution: nitrate in ground-water, eutrophication } \\
\text { of receiving waters and soils, fish toxicity, atmospheric particles }\end{array}$ \\
\hline Phosphorus & $\begin{array}{l}\text { Fertiliser } \\
\text { Raw product for chemical industry }\end{array}$ & $\begin{array}{l}\text { Environmental pollution (eutrophication) } \\
\text { Precipitates block pipes and valves }\end{array}$ \\
\hline Bicarbonate & None & Precipitates block pipes and valves \\
\hline Sulfur & $\begin{array}{l}\text { Fertiliser } \\
\text { Raw product for chemical industry }\end{array}$ & $\begin{array}{l}\text { Environmental pollution } \\
\text { Smell and toxicity of hydrogen sulfide }\end{array}$ \\
\hline Potassium & $\begin{array}{l}\text { Fertiliser } \\
\text { Raw product for chemical industry }\end{array}$ & Salinisation of agricultural soils and groundwater \\
\hline Sodium chloride & Raw product for chemical industry & Salinisation of agricultural soils and groundwater \\
\hline $\begin{array}{l}\text { Bulk organic } \\
\text { substances }\end{array}$ & None & $\begin{array}{l}\text { Pungent smell } \\
\text { Treatment problems such as foaming } \\
\text { Organic reduction of sulfate and nitrate: } \\
\text { sulfide production or } \mathrm{NO} \text { and } \mathrm{N}_{2} \mathrm{O} \text { production (pollutants, climate } \\
\text { gases) }\end{array}$ \\
\hline $\begin{array}{l}\text { Trace organic } \\
\text { compounds }\end{array}$ & None & $\begin{array}{l}\text { Human health concerns } \\
\text { Environmental concerns }\end{array}$ \\
\hline Pathogens & None & Human health concerns \\
\hline
\end{tabular}

TABLE 2

Concentrations in stored urine

The theoretical values are based on medical studies and include the morning urine (Udert et al., 2006). The values for the women's urine tank at Eawag were measured between 2011 and 2013 (between 5 and 106 samples; Etter et al., 2013). They are lower due to ammonia volatilisation, dilution and the absence of morning urine.

\begin{tabular}{|c|c|c|c|c|}
\hline \multirow[t]{2}{*}{ Variable } & \multirow[t]{2}{*}{ Unit } & \multirow[t]{2}{*}{ Theoretical value } & \multicolumn{2}{|c|}{ Women's tank at Eawag } \\
\hline & & & Mean & Standard deviation \\
\hline Total ammonia & $\mathrm{mg} \mathrm{N} \cdot \ell^{-1}$ & 8100 & 1790 & \pm 180 \\
\hline Total phosphate & $\mathrm{mg} P \cdot \ell^{-1}$ & 540 & 108 & \pm 14 \\
\hline Potassium & $\mathrm{mg} \cdot \ell^{-1}$ & 2200 & 897 & \pm 103 \\
\hline Sulphate & $\mathrm{mg} \cdot \ell^{-1}$ & 1500 & 316 & \pm 14 \\
\hline Calcium & $\mathrm{mg} \cdot \ell^{-1}$ & 0 & 10 & \pm 11 \\
\hline Magnesium & $\mathrm{mg} \cdot \ell^{-1}$ & 0 & $<5$ & \\
\hline Sodium & $\mathrm{mg} \cdot \ell^{-1}$ & 2600 & 966 & \pm 314 \\
\hline Chloride & $\mathrm{mg} \cdot \ell^{-1}$ & 3800 & 1830 & \pm 320 \\
\hline
\end{tabular}


TABLE 2 (continued)

Concentrations in stored urine

The theoretical values are based on medical studies and include the morning urine (Udert et al., 2006). The values for the women's urine tank at Eawag were measured between 2011 and 2013 (between 5 and 106 samples; Etter et al., 2013). They are lower due to ammonia volatilisation, dilution and the absence of morning urine.

\begin{tabular}{|l|c|c|c|c|}
\hline Variable & Unit & Theoretical value & \multicolumn{2}{|c|}{ Women's tank at Eawag } \\
\cline { 3 - 5 } & & & 3200 & 970 \\
\hline Inorganic carbon & $\mathrm{mg} \cdot \ell^{-1}$ & 10000 & 2110 & \pm 109 \\
\hline Chemical oxygen demand & $\mathrm{mg} \cdot \ell^{-1}$ & 9.1 & Median 8.9 & \pm 390 \\
\hline $\mathrm{pH}$ & {$[-]$} & & \\
\hline
\end{tabular}

\section{THE AIM OF URINE TREATMENT}

Urine treatment has to prevent possible negative effects of urine, such as environmental pollution, hygienic risks and malodour. Inadequate sanitation is reportedly the main source of high nitrate concentrations in South African groundwater (Tredoux, 2004) and a major cause of eutrophication in urban areas of sub-Saharan Africa (Nyenje et al., 2009). However, urine is also a source of valuable nutrients. By recovering these nutrients as a fertiliser, the nutrient cycle to agriculture is closed and the environmentally adverse production of synthetic fertilisers is reduced. Besides these beneficial effects for the environment, financial valorisation of human excreta could offset the costs of sanitation (Tilley and Günther, 2013). Thus, there are many justifications for the separate treatment of urine, but realistically, it will only be implemented on a large scale if the investment and operational costs are low and if the treatment technologies are reliable and easy to operate. Furthermore, nutrients have to be recovered in a form which allows direct application in agriculture or further treatment in the chemical industry.

\section{TECHNOLOGIES FOR URINE TREATMENT}

A wide range of processes for urine treatment has been proposed (Maurer et al., 2006) but only a few have been tested in the laboratory or at pilot scale (Larsen et al., 2013). To our knowledge, only the following 4 processes have been operated at pilot scale prior to the VUNA project:

- A combination of electrodialysis, microfiltration and ozonation (Pronk et al., 2007)

- Phosphorus recovery by struvite precipitation (Etter et al., 2011; Antonini et al., 2011; Winkler et al., 2013)

- Ammonia stripping (Antonini et al., 2011; Winkler et al., 2013)

- Acidification and solar evaporation (Antonini et al., 2012)

In many studies, urine has also been applied without intensive treatment, but some measures have to be taken to prevent hygienic and environmental risks. Höglund et al. (2002) recommend storing the urine for 6 months to ensure that pathogens (especially viruses) are inactivated. Furthermore, gentle spreading techniques have to be used to prevent high ammonia losses (Johansson, 2001).

For the VUNA project, we decided to investigate the following 3 processes:

- Struvite precipitation, because it has already been tested extensively in pilot studies and is a simple process to be implemented in the field

- Nitrification/distillation, because it is currently the only process combination for complete recovery of all nutrients in a small volume without chemical addition

- Electrolysis, because it allows building very small reactors, which could be integrated into toilets. On-site treatment would cut the costs of transportation

\section{Struvite precipitation}

Struvite precipitation is probably the best understood process for nutrient recovery from source-separated urine, because it has been tested in multiple pilot projects (Etter et al., 2011; Antonini et al., 2011; Winkler et al., 2013). The mineral struvite $\left(\mathrm{MgNH}_{4} \mathrm{PO}_{4} \cdot 6 \mathrm{H}_{2} \mathrm{O}\right)$ can easily be precipitated from stored urine, because most of the requirements (high $\mathrm{pH}$ value, high ammonia and phosphate concentrations) are given; only a magnesium source has to be added to precipitate nearly all phosphate as struvite (Wilsenach et al., 2007). Struvite precipitation only takes a few minutes if a very soluble magnesium source is used (Etter et al., 2011). Typical magnesium sources are magnesium salts such as $\mathrm{MgO}, \mathrm{MgCl}_{2}$, and $\mathrm{MgSO}_{4}$. The dissolution rate of $\mathrm{MgO}$ in urine is slightly slower than for $\mathrm{MgCl}_{2}$ and $\mathrm{MgSO}_{4}$, but $\mathrm{MgO}$ is substantially cheaper (Sakthivel et al., 2012). Some waste products are also suitable magnesium sources, for example bittern (waste brine left over after sea salt production; Ye et al., 2011) and wood ash (Sakthivel et al., 2012). In the latter case, pollution with heavy metals and precipitation of unwanted minerals can be problematic. A low overdose of $10 \%$ (that is $1.1 \mathrm{~mol} \mathrm{Mg} \cdot \mathrm{mol}^{-1} \mathrm{PO}_{4}$ ) is already sufficient to precipitate $95 \%$ of the phosphate as struvite, but overall struvite recovery is often limited by the efficiency of crystal recovery, for example during filtration (Etter et al., 2011). In order to maximise phosphate recovery from urine, the spontaneously precipitated phosphate in the collection tank has to be recovered as well (see above). Overall, struvite precipitation is a process for phosphorus recovery; however, while nearly all the dissolved phosphate can be removed, more than $97 \%$ of the nitrogen, and practically all the potassium and sulphur remain in the effluent (Etter et al., 2011).

\section{Nitrification and distillation}

The goal of a nitrification/distillation reactor setup is to recover the maximum of the urine's nutrient content (nitrification) and to concentrate the nutrients in a very low volume (distillation). By reducing the water volume, the costs for storage and transportation can be minimised. Nitrification is an aerobic biological process which involves 2 bacterial groups, i.e. ammoniaoxidising bacteria and nitrite-oxidising bacteria. The activities of both bacterial groups have to be well-balanced, otherwise, nitrite will accumulate and inhibit the nitrite- oxidising 
bacteria. During nitrification, half of the total ammonia in urine is oxidised to nitrate, while the $\mathrm{pH}$ is lowered to values close to 6 . Under such conditions, no considerable ammonia losses occur anymore (Udert et al., 2003b). Nitrate production is limited by the alkalinity in stored urine; after half of the ammonia is oxidised to nitrate, the process stops due to the low $\mathrm{pH}$ value. For complete conversion of ammonia to nitrate, alkalinity has to be added, for example by dosing $1 \mathrm{~mol} \mathrm{KHCO}$ per $1 \mathrm{~mol}$ total ammonia. Besides the 2 groups of nitrifying bacteria, heterotrophic bacteria are also involved in the biological treatment of urine. They degrade up to $90 \%$ of the organic substances (Udert et al., 2003b).

After sedimentation of the suspended biomass in a settler, the solution is fed to a distillation reactor. Distillation is an evaporation process, in which water is heated up to boiling point and then evaporated. Most of the energy is required for water evaporation, but this energy can be recovered, for example by vapour compression and subsequent heat exchange. Without preliminary stabilisation of urine by nitrification or acid dosage (Ek et al., 2006), high ammonia losses will occur during distillation of urine (Udert and Wächter, 2012).

\section{Electrolysis of urine}

High degradation rates per surface area and simple operation make electrolysis an interesting process for small reactors which could be directly integrated into a toilet. A complete treatment of urine at the household would cut the costs for transportation to a treatment plant. Possibly, only a small amount of by-products (e.g. electrochemically precipitated struvite) would have to be collected, while the remaining water could be infiltrated. Drawbacks of electrolysis are a high demand for electricity, high prices for some of the most efficient electrodes, and the production of chlorinated by-products (Anglada et al., 2009). Since ammonia is degraded and not recovered in most electrolysis processes, electolysis could be applied at locations where preventing hygiene and environmental problems is much more important than nutrient recovery and reuse.

Frequently, electrolytic oxidation processes in wastewater treatment are based on indirect oxidation. In most cases of indirect oxidation, chloride is oxidised anodically to active chlorine, which, in turn, oxidises compounds such as ammonia or organics. Active chlorine is also an efficient disinfectant, especially for viruses and bacteria (but to a lesser extent for protozoa; von Gunten, 2013). However, indirect oxidation is an unspecific process, which often produces considerable amounts of by-products, such as chlorinated organic substances, chlorate and perchlorate. A more specific electrolytic process is direct oxidation. In this case, the target compound, in our case mostly ammonia, is oxidised directly at the anode. Ideally, the anode potential, at which direct oxidation occurs, is below the potentials necessary to produce significant amounts of active chlorine or oxygen (Zöllig et al., 2015).

\section{RESULTS OF URINE TREATMENT IN VUNA}

\section{Struvite precipitation}

\section{Reactor setup}

We investigated 2 reactor setups: the first (Grau et al., 2012) is similar to a manually operated reactor built in a previous study in Nepal (Etter et al., 2011), the second is a fully automated reactor equipped with a process control for magnesium dosage (Grau et al., 2013). Besides the level of automation, the 2 setups also use different filtration methods: the manual reactor is equipped with cotton filter bags, which are later dried in the air (for 7 to $14 \mathrm{~d}$ ) and the automated version has a module with flat cotton filters, which can be used up to 7 times. For both setups, solutions of $\mathrm{MgSO}_{4}$ or $\mathrm{MgCl}_{2}$ were used as magnesium sources. When the magnesium solution was added manually, a magnesium to phosphate (Mg:P) ratio of 1.1:1 was used. The reactor volumes were $40 \ell$ for the manual and $50 \mathrm{l}$ for the automated version. The total processing time for the manual reactor was $50 \mathrm{~min}$, of which 45 min were needed for filtration and only $5 \mathrm{~min}$ to fill the reactor, mix its content, and let the precipitant react in the precipitation reactor.

\section{Automated magnesium dosage}

In most reactors for struvite precipitation from urine, magnesium is dosed at the beginning of a process cycle. In this approach, the phosphate concentration needs to be known exactly for exact magnesium dosage. In VUNA's automated reactor, turbidity or electrical conductivity were measured online, while the magnesium solutions were dosed continuously (Grau et al., 2013). Based on the online measurement signals, the endpoint of struvite formation could be predicted, which allowed for a more exact magnesium dosage. Turbidity measurements were
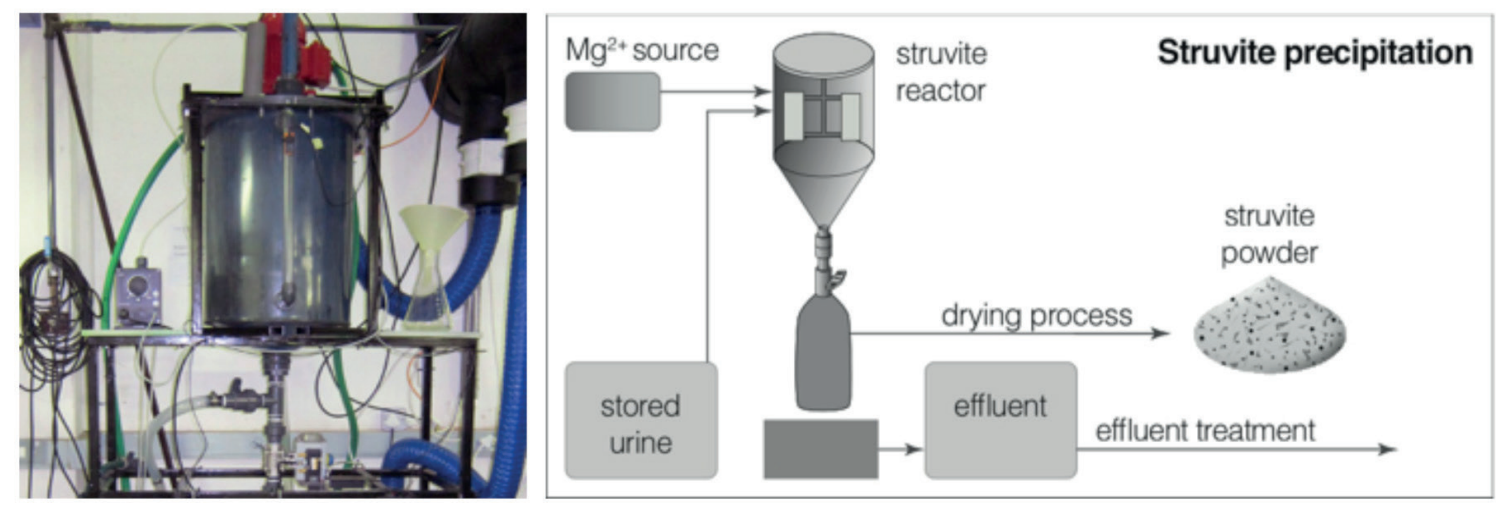

Figure 1

Set-up of the automated struvite reactor in the laboratory of the Pollution Research Group at the University of KwaZulu-Natal. The picture (by courtesy of Max Grau) shows the struvite reactor vessel.

http://dx.doi.org/10.4314/wsa.v41i2.06

Available on website http://www.wrc.org.za

ISSN 1816-7950 (On-line) = Water SA Vol. 41 No. 2 WISA 2014 Special Edition 2015

Published under a Creative Commons Attribution Licence 
more sensitive than electrical conductivity measurements; while the turbidity signal doubled between the beginning and the end of magnesium dosage, the conductivity signal changed only by 1 to $2 \%$, which is only slightly higher than typical measurement accuracies of $0.5 \%$. However, the conductivity signals better reflected the course of precipitation and allowed a more exact determination of the endpoint of struvite formation. Intermittent instead of continuous dosage resulted in more informative signals but the algorithms for process control also became more complex. Nevertheless, the experiments showed that online sensors can be used to optimise magnesium dosage.

\section{Electro-precipitation of struvite}

Besides being dosed as a powder or a solution, magnesium can also be dissolved electrochemically. Hug and Udert (2013) used a magnesium anode and a steel cathode to dissolve metallic magnesium for electro-precipitation of struvite. In a longterm experiment at an anode potential of $-0.6 \mathrm{~V}$ vs. NHE, the precipitation rate was $90 \mathrm{mg} \mathrm{P} \cdot \mathrm{cm}^{-2} \cdot \mathrm{d}^{-1}$. Electrochemical dissolution is more expensive than using $\mathrm{MgO}$ or waste products, but cost calculations show that it is in the same range or even less expensive than using $\mathrm{MgSO}_{4}$ or $\mathrm{MgCl}_{2}$. The energy demand is low (1.7 Wh per gram P precipitated), so that energy costs are negligible compared to the costs for the metallic magnesium. Combined with reliable process control, e.g. using turbidity measurements, electro-precipitation could be a promising approach for remote operation of on-site reactors.

\section{Fertiliser value}

In pot experiments with ryegrass, chemical fertiliser $\left(\mathrm{KH}_{2} \mathrm{PO}_{4}\right)$ and struvite precipitated from synthetic stored urine performed equally (Bonvin, 2013). By using isotopic tracers, a phosphorus uptake of $26 \%$ of phosphorus applied with struvite was determined, which was similar to the $28 \%$ of phosphorus taken up from the water soluble reference fertiliser. These results confirm previous studies on the fertiliser quality of struvite (Johnston and Richards, 2003; Römer, 2006). These studies also showed that struvite is a considerably better fertiliser than iron or aluminium phosphate recovered from wastewater.

\section{Pathogens and trace organic contaminants}

The fate of pathogens during struvite precipitation has been investigated by Decrey et al. (2011) and Schoger (2011). Decrey et al. focused on the most resistant pathogen groups, i.e. viruses and helminth eggs, and used phage $\Phi \mathrm{X} 174$ as indicator for human viruses and Ascaris suum as indicator for worm eggs. The study revealed that the majority of helminth eggs are retained in the struvite cake, which forms on the filter. The phage concentration in the struvite cake could be attributed to the phages in the pore water. Drying of struvite reduced the number of phages by more than $3 \log$ units (drying at $36^{\circ} \mathrm{C}$ and $35 \%$ to $42 \%$ relative humidity). The inactivation of phages was directly correlated to the moisture content of the struvite. Ascaris suum eggs inactivated to a much lower degree. Even at the minimum moisture content, the deactivation was only 2 log units. Schoger (2011) measured total heterotrophic bacteria as an indicator of bacterial pathogens. He found that bacteria also accumulated in struvite but died off as a function of struvite moisture content. However, inactivation levelled off around $3 \log$ loss.

Heating of struvite could deactivate all pathogens, but struvite is not stable at temperatures above $55^{\circ} \mathrm{C}$ (Bhuiyan et al., 2008); water and ammonia will be released and struvite is transformed first to dittmarite $\left(\mathrm{MgNH}_{4} \mathrm{PO}_{4} \cdot \mathrm{H}_{2} \mathrm{O}\right)$, and after further heating, to $\mathrm{MgHPO}_{4}$. Further studies should explore whether those 2 products are also good fertilisers. If this should be the case, heating might be a favourable post-treatment of struvite recovery given that environmental pollution and health impacts by ammonia loss can be prevented.

Retention of trace organic compounds was not investigated within VUNA, but, according to previous research, it is unlikely that struvite retains large amounts of pharmaceutical residues. Ronteltap et al. (2007) observed that pharmaceutical residues are not incorporated into struvite crystals during the crystallisation process. As an estimate, it can be assumed that the extent of pharmaceutical retention corresponds to the amount of urine in the pores of the struvite cake.

\section{Nitrification and distillation}

\section{Reactor setup}

Within the VUNA project, 2 reactor setups have been operated, one in Eawag's main building in Dübendorf/Switzerland (Fig. 2) and the other one in Durban, South Africa. The basic principle of both setups is the same: stored urine is pumped into a nitrification reactor, where Kaldnes $\mathrm{K} 1$ biofilm carriers (60\% of the reactor bulk volume) are used as substratum for the slow-growing nitrifying bacteria. Microbiological analyses with
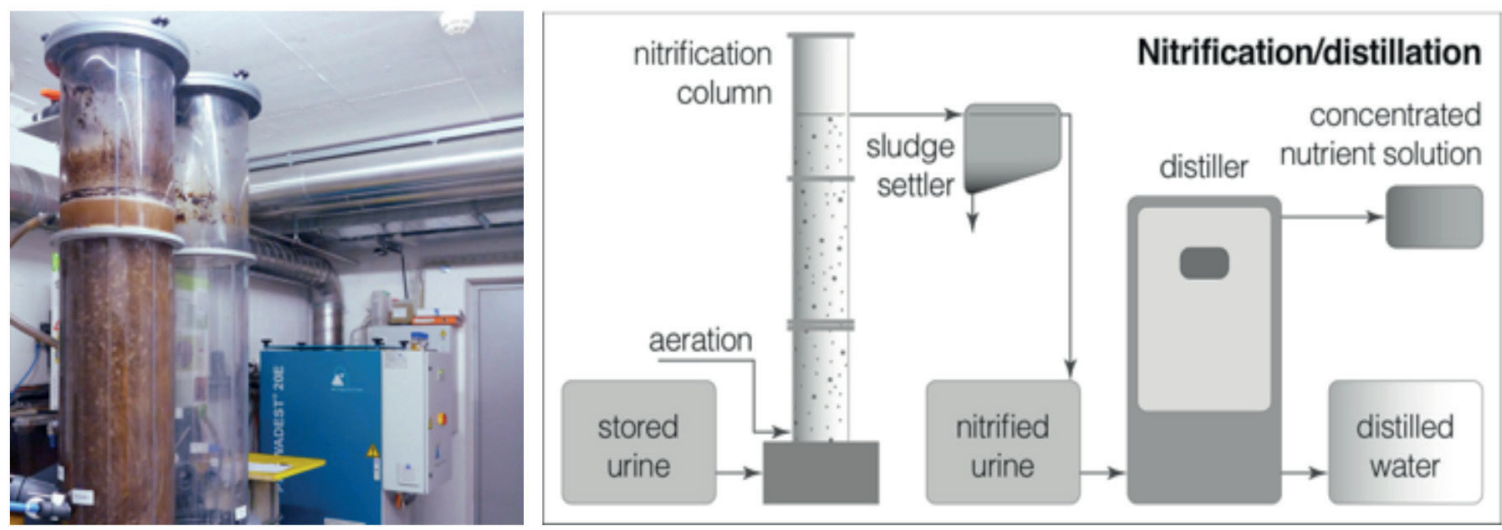

Figure 2

Nitrification/distillation setup at Eawag in Dübendorf

http://dx.doi.org/10.4314/wsa.v41i2.06 Available on website http://www.wrc.org.za 
polymerase chain reaction (authors> own unpublished data) have shown that the nitrifying bacteria grow mostly on the biofilm carriers, while heterotrophic bacteria also grow in suspension. The maximum nitrification rate was $420 \mathrm{mg} \mathrm{N} \cdot \mathrm{m}^{-3} \cdot \mathrm{d}^{-1}$ or $1.4 \mathrm{~g} \mathrm{~N} \cdot \mathrm{m}^{-2} \cdot \mathrm{d}^{-1}$. This is in the range of maximum nitrification rates reported by Rusten et al. (1995) for municipal wastewater treatment $\left(1.4\right.$ to $\left.1.6 \mathrm{~g} \mathrm{~N} \cdot \mathrm{m}^{2} \cdot \mathrm{d}^{-1}\right)$.

The distiller is a commercially available reactor produced by KMU-Loft Cleanwater (ProwaDest E20, KMU-Loft Cleanwater $\mathrm{GmbH}$, Hausen, Germany) with a minimum throughput of $20 \mathrm{l} \cdot \mathrm{h}^{-1}$. About $85 \%$ of the energy needed for evaporation is recovered by vapour compression and subsequent heat exchange. About $95-97 \%$ of the water in urine is removed and the remaining concentrate is still a liquid without precipitates. A solid product mainly consisting of ammonium nitrate can be recovered from this process by evaporating the remaining water. However, this final process step does not improve the product quality substantially and requires much more elaborate equipment. The solid ammonium nitrate product is also more sensitive to heat and can explode if heated. Wächter et al. (2013) showed that the solid ammonium nitrate product from urine should not be exposed to temperatures above $96^{\circ} \mathrm{C}$ for an extended period of time to prevent fast thermal decomposition. If all ammonia is oxidised to nitrate by adding a base to the influent urine, the sensitivity to high temperatures is not critical anymore within common temperature ranges for distillation and drying processes (Wächter, 2013). However, small amounts of ammonia make the product temperature sensitive. For example, the temperature limit for drying a 1:9 ammonium nitrate nitrified urine solution is $168^{\circ} \mathrm{C}$, but this is still substantially above the common temperature for distillation and drying processes. For the liquid products, the temperature limits are not critical: for the 1:1 ammonium nitrate solution, the limit is $211^{\circ} \mathrm{C}$. The temperature limit for the $1: 9$ ammonium nitrate solution was not determined, because the limit for the 1:1 ammonium nitrate solution is already far above the operating range of the distiller. In the current setup, the nitrified urine is heated to $80^{\circ} \mathrm{C}$ for several hours. These conditions are far from being critical for the thermal stability of ammonium nitrate, and they ensure disinfection. For comparison, pasteurisation of sewage sludge requires heating the sludge to $70^{\circ} \mathrm{C}$ for at least 30 min (US EPA, 2003).

\section{Nutrient recovery}

Nearly all nutrients are recovered in the final product except for a negligible amount of nutrients in the withdrawn excess sludge, and some ammonia, which volatilises during distillation (less than $3 \%$ of the total nitrogen in urine; Udert and Wächter, 2012). Since about $30 \%$ of the phosphate precipitates in the collection tanks and might not enter the nitrification reactor, the solids in the urine storage tanks should be collected as well in order to maximise nutrient recovery.

\section{Chemical requirements and energy demand}

The process combination of nitrification/distillation does not require any chemicals with the exception of a small amount of corrosion inhibitor for the distillation reactor. Adding a base will be necessary if all of the ammonia is supposed to be oxidised to nitrate. If the base $\mathrm{KHCO}_{3}$ was used, $7.1 \mathrm{~g} \mathrm{KHCO}_{3}$ per gram of total ammonia would be needed. Based on experience with the reactor at Eawag, the energy demand is about $50 \mathrm{Wh} \cdot \ell^{-1}$ for partial nitrification and $100 \mathrm{Wh} \cdot \ell^{-1}$ for complete nitrification (for undiluted urine). Distillation requires about $80 \mathrm{Wh} \cdot \ell^{-1}$. Additionally, pumps and process control will require some energy, so that our current estimate for the total energy demand is about $140 \mathrm{Wh} \cdot \ell^{-1}$.

\section{Process stability}

Since nitrification is a biological process, it is more sensitive to process disturbances than a chemical process. The most critical problem is nitrite accumulation (Udert and Wächter, 2012; Etter et al., 2013). Small changes in the inflow rate or in the reactor $\mathrm{pH}$ can destabilise the sensitive balance between ammonium and nitrite-oxidising bacteria, so that the intermediate nitrite can accumulate. Nitrite concentrations above approximately $50 \mathrm{mg} \mathrm{N} \cdot \ell^{-1}$ will require immediate action to prevent further accumulation, and inhibition of the nitrifying bacteria. Simulations have shown that an inflow increase of only $10 \%$ can lead to serious nitrite accumulation. (Etter et al., 2013). Nitrite detection will be a key feature of stable urine nitrification reactors.

\section{Fertiliser value}

Bonvin (2013) tested the availability of nitrogen from synthetic solutions representing nitrified urine in pot experiments with ryegrass (Bonvin, 2013). The plants took up about $75 \%$ of the nitrogen in nitrified urine, compared to $77 \%$ in the case of the chemical fertiliser $\left(\mathrm{NH}_{4} \mathrm{NO}_{3}\right)$. The advantage of urine-derived fertilisers is the content of other nutrients, which are often lacking in synthetic fertilisers. Therefore, it might be particularly well suited for regions where fertilisers are scarce and knowledge about optimal fertiliser application is low.

\section{Pathogens}

Nitrified urine contains some compounds of concern for fertilisers including pathogens, pharmaceutical residues and sodium chloride. Bischel et al. (2015) used bacteriophages to investigate the inactivation of viruses in laboratory-scale reactors for urine nitrification. The bacteriaphage Qbeta was inactivated by aeration, while 2 other bacteriophages ( $\Phi$ X147 and MS2) were hardly affected. However, the number of pathogenic bacteria (indicator organisms: Salmonella typhimerium, Enterococcus spp.) was reduced by about $1 \log$ unit due to microbial activity. Worm eggs are presumably not inactivated during nitrification, but could partially be removed by sedimentation in the settling tank or by filtration if a membrane reactor was used for nitrification. While nitrification might not be a safe barrier against pathogens, distillation ensures that all pathogens will be killed, so that the concentrated product will be hygienically safe.

\section{Trace organic contaminants}

To date, we have not investigated the degradation of pharmaceutical residues during distillation, but it is unlikely that a strong reduction will occur, because they are mostly stable at temperatures up to $80^{\circ} \mathrm{C}$. However, some pharmaceutical residues are degraded during nitrification. In a laboratory study with a nitrification reactor, we investigated the degradation of several pharmaceuticals (antibiotics, antivirals, beta blockers, 
analgesics, and diuretics), which were dosed to stored urine. The pharmaceuticals were chosen based on measurements in large urine collection tanks in eThekwini. Several antiviral and antibiotic compounds and the beta blocker Atenolol had half-life times of $9 \pm 3 \mathrm{~d}$ (Özel, 2013), which was shorter than the hydraulic retention time in the lab-scale reactor. However, some compounds were still detectable in considerable amounts in the effluent. To minimise the pharmaceutical load in the final product, the effluent of the nitrification reactor could be treated with activated carbon. Experiments with different dosages of activated carbon revealed that a near complete removal of the investigated pharmaceuticals is possible (Özel, 2013). In addition to removing the pharmaceuticals, the brown colour of the effluent is degraded. In a practical setting, a granular activated carbon filtration could be easily established.

\section{Sodium chloride removal}

Sodium chloride is not desirable in fertilisers due to the possible salinisation of agricultural soils. It should be noted that the ratio of nutrients to sodium and chloride in urine is not higher than in manure, which is commonly used as fertiliser (see e.g. Nunez-Delgado et al., 2002). Nevertheless, removing sodium chloride would further increase the quality of the urine-derived fertiliser. Laboratory experiments have revealed that up to $50 \%$ of the sodium chloride could be removed by sequential distillation at well-controlled and set temperatures (Huber, 2011). This might be an option for producing a fertiliser for agricultural soils with low tolerance for sodium chloride. However, for many soils the impact of sodium chloride from urine-derived fertiliser is probably too low to justify the higher complexity of a distillation process with sequential salt removal.

\section{Electrolysis}

\section{Direct oxidation on graphite electrodes}

Graphite is a cheap electrode material, which has been used traditionally for chlorine production (Hamann and Vielstich, 2007). While it is inexpensive, it is not stable at anode potentials in the chlorine evolution range and cannot be used for indirect oxidation of urine in the long term. However, below this range (below an anode potential of $1.6 \mathrm{~V}$ vs. SHE), graphite can be used for direct oxidation of compounds such as ammonia (Zöllig et al., 2015). Our experiments (Zöllig et al., 2015) on direct ammonia oxidation on graphite electrodes showed that this process requires high $\mathrm{pH}$ values, preferably above the $p K_{\mathrm{a}}$ value for ammonia $\left(9.5\right.$ at $25^{\circ} \mathrm{C}$ and an ionic strength of $0.5 \mathrm{~mol} \cdot \ell^{-1}$ ) (Stumm and Morgan, 1996), because free ammonia $\left(\mathrm{NH}_{3}\right)$ is the actual reactant on the electrode surface. In stored urine, the $\mathrm{pH}$ is slightly below this value, which might explain why the degradation in the batch experiments was only $5.2 \mathrm{~g} \mathrm{~N} \cdot \mathrm{m}^{-2} \cdot \mathrm{d}^{-1}$ (at $1.31 \mathrm{~V}$ vs. SHE). In comparison, indirect oxidation of ammonia on graphite proceeded at a rate of $150 \mathrm{~g} \mathrm{~N} \cdot \mathrm{m}^{2} \cdot \mathrm{d}^{-1}$ (at $1.94 \mathrm{~V}$ vs. SHE) and the biological nitrification rate in a moving bed biofilm reactor can be $1.6 \mathrm{~g} \mathrm{~N} \cdot \mathrm{m}^{-2} \cdot \mathrm{d}^{-1}$, which is only slightly lower. The energy demand per mass of $\mathrm{N}$ was $44 \mathrm{Wh} \cdot \mathrm{g}^{-1}$ and $87 \mathrm{Wh} \cdot \mathrm{g}^{-1}$ for direct and indirect oxidation respectively, and therefore significantly higher than the energy demand for nitrification (about $6 \mathrm{Wh} \cdot \mathrm{g}^{-1}$ ). Direct ammonia oxidation with graphite is a suitable process, if the $\mathrm{pH}$ is kept high, large electrode surface areas are provided and the anode potential can be kept constant. All these requirements are hard to fulfil in small on-site reactors. However, a major advantage of direct oxidation on graphite is that the formation of chlorinated by-products can be prevented.

\section{Indirect electro-oxidation}

In our experiments (authors' own unpublished data), we used 2 common anodes for indirect electro-oxidation, a noble metal oxide electrode TDIROF (thermally decomposed iridium oxide film) and BDD (boron-doped diamond). With indirect electrooxidation it is not necessary to adjust a certain anode potential, and the simpler and more common operational mode of applying a constant current density was chosen. Both electrodes can also be used for direct ammonia oxidation (Kapalka et al., 2010; Kapalka et al., 2011), but in these experiments, indirect oxidation was dominant due to the high anode potentials that resulted from the high current densities we applied. Preliminary results showed that depending on the current density, very high removal rates can be achieved. At the highest current density $\left(20 \mathrm{~mA} \cdot \mathrm{cm}^{-2}\right)$, the maximum removal rates for organic substances were higher than $500 \mathrm{~g} \mathrm{COD} \cdot \mathrm{m}^{-2} \cdot \mathrm{d}^{-1}$ for TDIROF and $1000 \mathrm{~g} \mathrm{COD} \cdot \mathrm{m}^{2} \cdot \mathrm{d}^{1}$ for $\mathrm{BDD}$. The maximum ammonia removal rates were above $400 \mathrm{~g} \mathrm{~N} \cdot \mathrm{m}^{2} \cdot \mathrm{d}^{-1}$ and $200 \mathrm{~g} \mathrm{~N} \cdot \mathrm{m}^{-2} \cdot \mathrm{d}^{-1}$ for TDIROF and BDD, respectively. Unfortunately, the excellent removal rates came with a price: the energy consumption was high and considerable amounts of chlorinated by-products were produced. Even at ideal conditions (high ammonia concentrations and new electrodes) the energy consumption per mass of $\mathrm{N}$ removed was above $40 \mathrm{Wh} \cdot \mathrm{g}^{-1}$ and $200 \mathrm{Wh} \cdot \mathrm{g}^{-1}$ for TDIROF
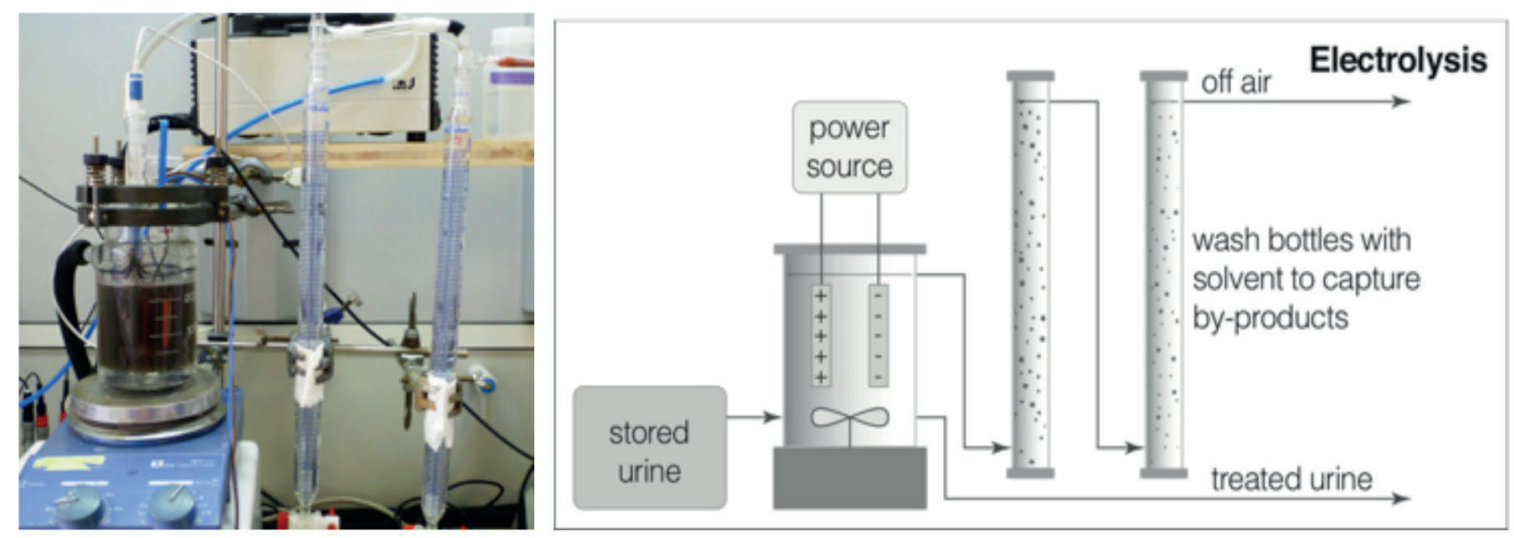

Figure 3

Laboratory setup at Eawag to determine the production of chlorinated by-products during urine electrolysis 
and BDD, respectively. There were two reasons for the high energy consumption with BDD. Firstly, the current efficiency for ammonia oxidation with BDD was only $20 \%$ compared to $50 \%$ for TDIROF, which could be explained by a higher preference of BDD for oxidising organic substances. Secondly, BDD required a higher cell voltage, $6 \mathrm{~V}$ compared to about $4 \mathrm{~V}$ with TDIROF at $20 \mathrm{~mA} \cdot \mathrm{cm}^{-2}$ ).

\section{By-product formation}

Whereas no chlorinated organic or inorganic by-products were found for direct oxidation on graphite, considerable amounts were detected in the experiments on indirect oxidation with TDIROF and BDD (authors' own unpublished data). The chlorinated organic by-products were extracted from the urine and were captured in the off-gas to determine the amount of volatilised compounds. Six compounds were quantified with coupled gas chromatography/mass spectrometry (GC/MS): 1,2 dichloroethane, 1,2 dichloropropane, chlorobenzene, dichloromethane, trichloromethane, tetrachloromethane. Our preliminary measurements showed that about $50-100 \%$ of the chlorinated organic by-products volatilised. While $\mathrm{BDD}$ was more prone to the production of chlorinated organic by-products, chlorate formation was doubled on TDIROF compared to BDD. Our results suggest that in practical settings for urine electrolysis, chlorinated by-products have to be captured in the off-gas as well as in the effluent to prevent health and environmental hazards.

\section{SUMMARY}

Table 3 provides an overview of criteria which are relevant for the choice of urine treatment technologies. Electrolysis, especially indirect oxidation, is a promising process with respect to sanitisation and removal of nitrogen and organic compounds. However, the process does not allow the recovery of most nutrients and might even pose a health risk due to the production of chlorinated by-products. Further research and development and a combination with other processes will be necessary to make electrolysis a suitable process for on-site urine treatment.

Struvite precipitation and nitrification/distillation have been tested at pilot scale and are close to commercialisation. Both processes target different markets. Struvite precipitation does not require complex reactor setups and can be operated by non-skilled workers. It is an efficient process for phosphorus recovery, but most nutrients end up in the effluent. Furthermore, sanitisation of struvite is incomplete without long drying phases. A combination with other processes, for example nitrification/distillation to treat the effluent, or heating of struvite for pathogen deactivation (and struvite transformation to $\mathrm{MgHPO}_{4}$ ) is advisable.

Nitrification/distillation fulfils all requirements with respect to nutrient recovery, environmental protection and sanitisation, but the process is more complex and technically challenging than struvite precipitation. Water removal can even become dangerous, if the temperatures are high (above $96^{\circ} \mathrm{C}$ ) and solid ammonium nitrate is produced. This problem could be solved by reliable automation, or by using other water

TABLE 3

Comparison of struvite precipitation, nitrification/distillation and electrolysis according to the research results in VUNA

\begin{tabular}{|c|c|c|c|}
\hline & Struvite precipitation & Nitrification/Distillation & Electrolysis \\
\hline Main product & Phosphate mineral (struvite) & $\begin{array}{l}\text { Concentrated, complete nutrient } \\
\text { solution }\end{array}$ & $\begin{array}{l}\text { Effluent without ammonia, organic sub- } \\
\text { stances and pathogens }\end{array}$ \\
\hline Nutrient recovery & $\begin{array}{l}\text { Medium, } \\
\text { mainly phosphate }\end{array}$ & $\begin{array}{l}\text { High, } \\
\text { nearly all nutrients }\end{array}$ & $\begin{array}{l}\text { None, if not combined with other } \\
\text { processes }\end{array}$ \\
\hline Nutrient loss & $\begin{array}{l}\text { High, } \\
\text { most nutrients in the effluent }\end{array}$ & $\begin{array}{l}\text { Low, } \\
\text { little ammonia } \\
\text { volatilisation }\end{array}$ & $\begin{array}{l}\text { High } \\
\text { ammonia is oxidised to nitrogen }\end{array}$ \\
\hline Sanitisation & $\begin{array}{l}\text { Medium, } \\
\text { depends on drying procedure }\end{array}$ & $\begin{array}{l}\text { High, } \\
\text { complete disinfection during distillation }\end{array}$ & $\begin{array}{l}\text { Medium } \\
\text { chlorination }\end{array}$ \\
\hline Malodour removal & No & Yes & Yes \\
\hline $\begin{array}{l}\text { Removal of trace } \\
\text { organic compounds }\end{array}$ & No & Partial degradation during nitrification & Unknown \\
\hline Energy demand $^{(1)}$ & $\begin{array}{l}\text { Very low, especially for manual } \\
\text { reactor }\end{array}$ & $\begin{array}{l}\text { Medium } \\
\text { approx. } 50 \mathrm{Wh} \cdot \ell_{\text {urine }}^{-1} \text { partial nitrification } \\
\text { approx. } 80 \mathrm{Wh} \cdot \ell_{\text {urine }}{ }^{-1} \text { distillation }\end{array}$ & $\begin{array}{l}\text { High, } \\
\text { approx. } 320 \mathrm{Wh} \cdot \ell_{\text {urine }^{-1}}(\text { TDIROF) } \\
\text { approx. } 1600 \mathrm{Wh} \cdot \ell_{\text {urine }}(\text { (BDD) }\end{array}$ \\
\hline $\begin{array}{l}\text { Volume reduction of } \\
\text { main product }\end{array}$ & $\begin{array}{l}\text { High, } \\
\text { phosphorus in struvite } 250 \text { to } \\
630 \text { times concentrated }^{(2)}\end{array}$ & $\begin{array}{l}\text { High, } \\
20 \text { to } 30 \text { times concentrated }\end{array}$ & No volume reduction \\
\hline Other outputs & Phosphate depleted urine & $\begin{array}{l}\text { Distilled water, } \\
\text { excess sludge }\end{array}$ & $\begin{array}{l}\text { Off-gas with chlorinated } \\
\text { by-products }\end{array}$ \\
\hline Process complexity & $\begin{array}{l}\text { Low (manual reactor) } \\
\text { Medium (automated reactor) }\end{array}$ & High & Low \\
\hline Development level & High & High & Low \\
\hline
\end{tabular}

(1) Calculated for a total ammonia concentration of $8 \mathrm{~g} \mathrm{~N} \cdot \ell^{-1}$. The values for electrolysis are based on the experimental values given in the text. These values are most probably too high, because they are based on small-scale laboratory experiments, which have not been optimised for low energy demand.

(2) Assuming phosphate concentrations between 200 and $500 \mathrm{mg} P \cdot \ell^{-1}$ in stored urine. 
removal processes which do not require high temperatures, for example humidification or reverse osmosis.

Removal of trace organic compounds, specifically pharmaceutical residues, might be necessary to license any fertiliser product from urine. However, it is unclear whether these compounds actually pose a major risk to the environment and human health when the urine fertilisers are applied to agricultural soils. Based on our current state of knowledge, removal of pathogens is much more important for human health.

High energy demand can be prohibitive for nitrification/ distillation (and electrolysis) if the reactors are supposed to be operated in remote locations, where no centralised or decentralised energy supply (e.g. solar cells) is available. However, the energy demand of all processes is so low, that it should not pose a serious problem in cities, where at least intermediate volumes of electricity supply can be guaranteed.

\section{ACKNOWLEDGEMENTS}

The VUNA project was initiated and has been funded by the Bill \& Melinda Gates Foundation. We received additional support from the National Science Foundations of Switzerland and the United States. We also thank the involved research institutes and the eThekwini Municipality for support with internal funds.

\section{REFERENCES}

ANGLADA A, URTIAGA A and ORTIZ I (2009) Contributions of electrochemical oxidation to waste-water treatment: Fundamentals and review of applications. J. Chem. Tech. Biotech. 84 (12) 1747-1755.

ANTONINI S, NGUYEN PT, ARNOLD U, EICHERT T and CLEMENS J (2012) Solar thermal evaporation of human urine for nitrogen and phosphorus recovery in Vietnam. Sci. Total Environ. 414 592-599.

ANTONINI S, PARIS S, EICHERT T and CLEMENS J (2011) Nitrogen and phosphorus recovery from human urine by struvite precipitation and air stripping in Vietnam. CLEAN - Soil, Air, Water 39 (12) 1099-1104.

BHUIYAN MIH, MAVINIC DS and KOCH FA (2008) Thermal decomposition of struvite and its phase transition. Chemosphere $\mathbf{7 0}$ (8) $1347-1356$

BISCHEL HN, SCHERTENLEIB A, FUMASOLI A, UDERT KM and KOHN T (2015) Inactivation kinetics and mechanisms of viral and bacterial pathogen surrogates during urine nitrification. Environ. Sci.: Water Res. Technol. 1 (1) 65-76.

BONVIN C (2013) Recycling of phosphorus and nitrogen from human urine: evaluation of two urine-based fertilizers. Master's thesis, Swiss Federal Institute of Technology Zurich, Institute of Agricultural Sciences, Group of Plant Nutrition.

BRUCE GM, PLEUS RC and SNYDER SA (2010) Toxicological relevance of pharmaceuticals in drinking water. Environ. Sci. Technol. 44 (14) 5619-5626.

DECREY L, UDERT KM, TILLEY E, PECSON BM and KOHN T (2011) Fate of the pathogen indicators phage ФX174 and Ascaris suum eggs during the production of struvite fertilizer from sourceseparated urine. Water Res. 45 (16) 4960-4972.

DWAF (DEPARTMENT OF WATER AFFAIRS AND FORESTRY) (2001) The White paper on Basic Household Sanitation. Department of Water Affairs and Forestry, Pretoria, South Africa.

EK M, BERGSTRÖM R, BJURHEM JE, BJÖRLENIUS B and HELLSTRÖM D (2006) Concentration of nutrients from urine and reject water from anaerobically digested sludge. Water Sci. Technol. $54(11-12)$ 437-444.

ETTER B, HUG A and UDERT KM (2013) Total nutrient recovery from urine - operation of a pilot-scale nitrification reactor. In: Proceedings of WEF/IWA Nutrient Removal and Recovery 2013: Trends in Resource Recovery and Use, 28-31 July 2013, Vancouver, Canada.
ETTER B, TILLEY E, KHADKA R and UDERT KM (2011) Low-cost struvite production using source-separated urine in Nepal. Water Res. 45 (2) 852-862.

GOUNDEN T, PFAFF B, MACLEOD N and BUCKLEY C (2006) Provision of free sustainable basic sanitation: the Durban experience. In: Proceedings of the $32^{\text {nd }}$ WEDC Conference - Sustainable Development of Water Resources, Water Supply and Environmental Sanitation. 3-6 November 2006, Colombo, Sri Lanka.

GRAU M, ETTER B, UDERT KM, BROUCKAERT CJ and BUCKLEY CA (2012) Development and operation of struvite reactors to recover phosphorus from source separated urine in eThekwini. In: Proceedings of the WISA 2012 Biennial Conference \& Exhibition, 6-10 May 2012, Cape Town, South Africa.

GRAU MGP, RHOTON SL, BROUCKAERT CJ and BUCKLEY CA (2013) Development of a fully automated struvite reactor to recover phosphorus from source separated urine collected at urine diversion toilets in eThekwini. In: Proceedings of WEF/IWA Nutrient Removal and Recovery 2013: Trends in Resource Recovery and Use, 28-31 July 2013, Vancouver, Canada.

HAMANN CH and VIELSTICH W (2007) Electrochemistry. Wiley$\mathrm{VCH}$, Weinheim, Germany. $404 \mathrm{pp}$.

HÖGLUND C, ASHBOLT N, STENSTRÖM TA and SVENSSON L (2002) Viral persistence in source-separated human urine. $A d v$. Environ. Res. 6 (3) 265-275.

HÖGLUND C, STENSTRÖM TA, JÖNSSON H and SUNDIN A (1998) Evaluation of faecal contamination and microbial die-off in urine separating sewage systems. Water Sci. Technol. 38 (6) 17-25.

HUBER S (2011) Temperature dependent removal of sodium chloride $(\mathrm{NaCl})$ from synthetic nitrified urine. Master's thesis, Swiss Federal Institute of Aquatic Science and Technology, Dübendorf, and Karlsruhe Institute of Technology.

HUG A and UDERT KM (2013) Struvite precipitation from urine with electrochemical magnesium dosage. Water Res. 47 (1) 289-299.

HUG A, MORGENROTH E and UDERT KM (2013) Free ammonia limitation and nitrous acid inhibition cannot explain the low $\mathrm{pH}$ limit of ammonia oxidizing bacteria. In: Proceedings of WEF/IWA Nutrient Removal and Recovery 2013: Trends in Resource Recovery and Use, 28-31 July, 2013, Vancouver, Canada.

JOHANSSON M (2001) Urine separation - closing the nutrient cycle. Stockholm Water Company, Stockholm.

JOHNSTON AE and RICHARDS IR (2003) Effectiveness of different precipitated phosphates as phosphorus sources for plants. Soil Use Manage. 19 (1) 45-49.

KAPALKA A, FIERRO S, FRONTISTIS Z, KATSAOUNIS A, NEODO S, FREY O, DE ROOIJ N, UDERT KM and COMNINELLIS C (2011) Electrochemical oxidation of ammonia $\left(\mathrm{NH}_{4}^{+} / \mathrm{NH}_{3}\right)$ on thermally and electrochemically prepared $\mathrm{IrO}_{2}$ electrodes. Electrochim. Acta 56 (3) 1361-1365.

KAPALKA A, JOSS L, ANGLADA A, COMNINELLIS C and UDERT KM (2010) Direct and mediated electrochemical oxidation of ammonia on boron-doped diamond electrode. Electrochem. Comm. 12 (12) 1714-1717.

LARSEN TA and GUJER W (1996) Separate management of anthropogenic nutrient solutions (human urine). Water Sci. Technol. 34 (3-4) 87-94.

LARSEN TA, UDERT KM and LIENERT J (2013) Source separation and decentralization for wastewater management, IWA Publishing, London, UK.

MAURER M, PRONK W and LARSEN TA (2006) Treatment processes for source-separated urine. Water Res. 40 (17) 3151-3166.

NUNEZ-DELGADO A, LOPEZ-PERIAGO E and DIAZ-FIERROS VIQUEIRA F (2002) Chloride, sodium, potassium and faecal bacteria levels in surface runoff and subsurface percolates from grassland plots amended with cattle slurry. Bioresour. Technol. 82 (3), 261-271.

NYENJE PM, FOPPEN JW, UHLENBROOK S, KULABAKO R and MUWANGA A (2009) Eutrophication and nutrient release in urban areas of sub-Saharan Africa - A review. Sci. Total Environ. 408 (3) 447-455.

ÖZEL BD (2013) Fate of pharmaceuticals during urine treatment in laboratory batch experiments: can urine be used as fertilizer in South Africa? Master's thesis, Swiss Federal Institute of Technology Zurich, Institute of Biogeochemistry and Pollutant Dynamics. 
PRONK W, ZULEEG S, LIENERT J, ESCHER B, KOLLER M, BERNER A, KOCH G and BOLLER M (2007) Pilot experiments with electrodialysis and ozonation for the production of a fertiliser from urine. Water Sci. Technol. 56 (5) 219-227.

ROMA E, PHILP K, BUCKLEY C, XULU S and SCOTT D (2013) User perceptions of urine diversion dehydration toilets: Experiences from a cross-sectional study in eThekwini Municipality. Water SA 39 (2) $305-312$

RÖMER W (2006) Plant availability of $\mathrm{P}$ from recycling products and phosphate fertilizers in a growth-chamber trial with rye seedlings. J. Plant Nutr. Soil Sci. 169 (6) 826-832. (in German)

RONTELTAP M, MAURER M and GUJER W (2007) The behaviour of pharmaceuticals and heavy metals during struvite precipitation in urine. Water Res. 41 (9) 1859-1868.

RUSTEN B, HEM LJ and ØDEGAARD H (1995) Nitrification of municipal wastewater in moving-bed biofilm reactors. Water Environ. Res. 67 (1) 75-86.

SAKTHIVEL SR, TILLEY E and UDERT KM (2012) Wood ash as a magnesium source for phosphorus recovery from source-separated urine. Sci. Total Environ. 419 68-75.

SCHOGER M (2011) Bacterial inactivation in struvite recovered from urine in South Africa. Master's thesis, Swiss Federal Institute of Technology, Lausanne, School of Architecture, Civil and Environmental Engineering.

SIEGRIST H, LAURENI M and UDERT KM (2013) Transfer into the gas phase: ammonia stripping. In Larsen TA, Udert KM and Lienert J (eds) Source Separation and Decentralization for Wastewater Management, IWA Publishing, London, UK.

STUMM W and MORGAN JJ (1996) Aquatic Chemistry. Wiley, New York, USA.

TILLEY E and GÜNTHER I (2013) Collection based on incentives: Encouraging urine collection with financial incentives. URL: http://www.eawag.ch/forschung/eng/gruppen/vuna/documentation/3-1_131203_VUNAbrochure_economics (Accessed 3 December 2014).

TREDOUX G (2004) Nitrate and associated hazard quantification and strategies for protecting rural water supplies. Research Report No. 1058/1/04, Water Research Commission, Pretoria, South Africa.

TROCCAZ M, NICLASS Y, ANZIANI P and STARKENMANN C (2013) The influence of thermal reaction and microbial transformation on the odour of human urine. Flavour Fragrance J. 28 (4) $200-211$.
UDERT KM and WÄCHTER M (2012) Complete nutrient recovery from source-separated urine by nitrification and distillation. Water Res. 46 (2) 453-464

UDERT KM, FUX C, MÜNSTER M, LARSEN TA, SIEGRIST H and GUJER W (2003b) Nitrification and autotrophic denitrification of source-separated urine. Water Sci. Technol. 48 (1) 119-130.

UDERT KM, LARSEN TA and GUJER W (2006) Fate of major compounds in source-separated urine. Water Sci. Technol. 54 (11-12) 413-420.

UDERT KM, LARSEN TA, BIEBOW M and GUJER W (2003a) Urea hydrolysis and precipitation dynamics in a urine-collecting system. Water Res. 37 (11) 2571-2582.

US EPA (UNITED STATES ENVIRONMENTAL PROTECTION AGENCY) (2003) Control of Pathogens and Vector Attraction in Sewage Sludge. United States Environmental Protection Agency, National Risk Management Research Laboratory, Cincinnati, OH, USA.

VON GUNTEN U (2013) Chemical oxidation processes. In: Larsen TA, Udert KM and Lienert J (eds) Source Separation and Decentralization for Wastewater Management, IWA Publishing, London, UK.

WÄCHTER M (2013) Distillation. Producing a concentrated urine fertiliser. URL: http://www.eawag.ch/forschung/eng/gruppen/ vuna/documentation/1-2_131203_VUNAbrochure_distillation (Accessed 3 December 2014).

WILSENACH JA, SCHUURBIERS CAH and VAN LOOSDRECHT MCM (2007) Phosphate and potassium recovery from source separated urine through struvite precipitation. Water Res. 41 (2) 458-466.

WINKLER M-KH, ROSSUM FV, OSKAM N, DIJK LV and POL GJVD (2013) Saniphos ${ }^{\circledast}$ technology for the recovery of ammonium and phosphate from human urine. In: Proceedings of WEF/IWA Nutrient Removal and Recovery 2013: Trends in Resource Recovery and Use, 28-31 July, 2013, Vancouver, Canada.

YE ZL, CHEN SH, LU M, SHI JW, LIN LF and WANG SM (2011) Recovering phosphorus as struvite from the digested swine wastewater with bittern as a magnesium source. Water Sci. Technol. 64 (2) 334-340.

ZÖLLIG H, FRITZSCHE C, MORGENROTH E and UDERT KM (2015) Direct electrochemical oxidation of ammonia on graphite as a treatment option for stored source-separated urine. Water Res. $69284-295$. 